\title{
Akut Miyokard Enfarktüsünü Taklit Eden Akut Miyoperikardit
}

\section{Acute Myopericarditis Mimicking Acute Myocardial Infarction}

\author{
Seval Izdeş, Neriman Defne Altıntaş*, Gülin Karaaslan*, Recep Uygun, Abdulkadir But \\ Yıldırım Beyazıt Üniversitesi, Atatürk Eğitim ve Araştırma Hastanesi Anesteziyoloji ve Reanimasyon Anabilim Dalı, Yoğun Bakım Ünitesi, Ankara, Türkiye \\ Atatürk Eğitim ve Araştırma Hastanesi Yoğun Bakım Ünitesi, Ankara, Türkiye
}

\section{ÖZET}

Yoğun bakımda izlenmekte olan genç hastalarda akut koroner sendrom yaşıllara göre daha nadir görülmektedir. Akut koroner sendroma benzeyen elektrokardiyografik anormallikler, koroner sendrom dışı nedenlerle de oluşabilir ve ayırıcı tanı çoğu zaman dikkatli bir değerlendirmeyi gerektirir. Bu olgu sunusunda, akut ST ve kardiyak enzim yükselmesiyle ortaya çıkan, akut koroner sendroma benzeyen miyoperikarditli bir olgu sunuldu ve miyoperikarditi akut koroner sendromdan ayırt etmede kullanılan yaklaşımlar literatür incelenerek tartışıldı. (Türk Yoğun Bakım Derneği Dergisi 2011; 9:68-70) Anahtar Kelimeler: Mediastinit, miyoperikardit; ayıııcı tanı

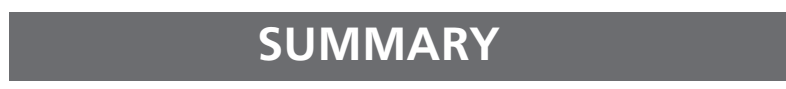

Acute coronary syndromes among young adults are relatively low when compared with older population in the intensive care unit. Electrocardiographic abnormalities mimicking acute coronary syndromes may be caused by non-coronary syndromes and the differential diagnosis requires a detailed evaluation. We are reporting a case of myopericarditis presenting with acute ST elevation and elevated cardiac enzymes simulating acute coronary syndrome. In this case report, the literature is reviewed to discuss the approach to distinguish an acute coronary syndrome from myopericarditis. (Journal of the Turkish Society Intensive Care 2011; 9:68-70) Key Words: Mediastinitis, myopericarditis; differential diagnosis 


\section{Giriş}

Yoğun bakım ünitelerinde (YBÜ) tedavi edilen hastalarda; ritim bozuklukları, akut koroner sendrom, gibi yeni başlayan kardiyovasküler problemlerle sıklıkla karşılaşılmaktadır (1). YBÜ'ndeki hastaların komplike durumları, kardiyovasküler problemlerin ayırıcı tanısı için çoğu zaman dikkatli ve ayrıntılı bir değerlendirme yapmayı gerektirmektedir. Çünkü bazen nadir görülen durumlar dikkatli bir değerlendirme yapılmadığında, daha sık görülen patolojiler ile karışabilmekte ve bu da hastaların tedavi planını ve yaşam şansını değiştirmektedir. Bu olgu sunusunda diş apsesine bağlı derin servikal enfeksiyon ve buna bağlı mediastinit tanısı ile opere olduktan sonra, YBÜ'nde entübe olarak izlenirken, akut ST yükselmesi olan bir olguyu sunup; akut koroner sendromdan ayırt etmenin önemine dikkat çekmeyi amaçladık.

\section{Olgu}

30 yaşındaki erkek hasta, boyunda şişlik ve ağrı şikâyetleri ile acil servise başvurmuş. Diş apsesine bağlı derin servikal enfeksiyon ve buna bağlı mediastinit tanısı ile acil olarak operasyona alınmış. Servikal apsesi direne edilen ve mediastinal direnaj tüpleri yerleştirilen, hemodinamik olarak stabil olmayan hasta postoperatif yoğun bakım ünitesinde entübe olarak izleme alındı. Taşikardik (140 atım/dk) ve hafif hipotansif $(80 / 40 \mathrm{mmHg}$ ) olan hasta sıvı tedavisine yanıt verdi. Tam kan sayımında Hb 15.2 g/dL, Hct \%41,5, trom-

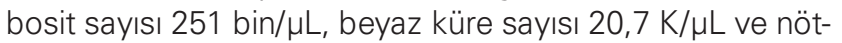
rofil sayısı 19,1 K/ $\mathrm{LL}(\% 92,6)$ olarak belirlendi. C-reaktif protein düzeyi 187 ve eritrosit sedimantasyon hızı 83 $\mathrm{mm} /$ saat saptandı. Sepsis tablosu nedeniyle ampirik olarak klindamisin ve imipenem başlandı. Apse materyalinden ekilen kültürde Moraxella species üredi. Klindamisin kesilerek, moksifloksasin başlandı. Hastanın önceden bilinen bir hastalığı, ilaç kullanım öyküsü ve sigara alışkanlığı yoktu.

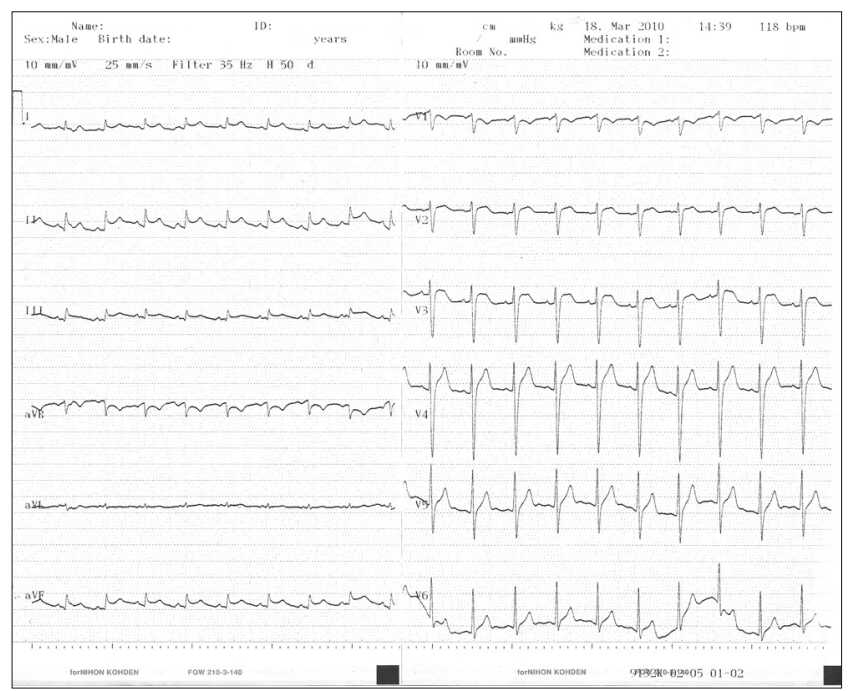

Resim 1. ST segment elevasyonunu gösteren elektrokardiyogram
Postoperatif 2. günde çekilen elektrokardiyogramında II, III ve aVF derivasyonlarında $2 \mathrm{~mm}$ 'nin üzerinde ST yükselmesi ve aVR derivasyonunda resiprokal değişiklikler görüldü (Resim 1). Hastanın sedasyon altında olması nedeni ile göğüs ağrısı sorgulanamadı. Vital bulgularında yeni gelişen bir değişiklik yoktu (TA: 130/70 mmHg, Nabız: 130 atım/dk, sinüs ritminde). Fizik muayenesinde kardiyak üfürüm ya da frotman duyulmadı. Kardiyak enzimlerinde hafif bir artış mevcuttu (Trop I: 0,24 ng/ml, CK: 356 U/L, CK-MB: 2,1 $\mathrm{ng} / \mathrm{ml})$. Risk faktörlerinin olmaması ve genç yaşına rağmen, akut koroner sendrom ayırt edilemedi. Ekokardiyografi ile değerlendirilen hastanın miyokard fonksiyonları normaldi, bölgesel duvar hareket bozukluğu yoktu, minimal perikardiyal sıvısı mevcuttu. Kardiyoloji bölümü tarafından akut koroner sendrom tanısını dışlamak amacı ile anjiografi yapıldı ve koroner damarları normal olarak değerlendirildi. Hastanın durumu nedeni ile manyetik rezonans ya da biyopsi gibi ileri tetkikler yapılamadı. Non-steroid anti-inflamatuar ilaç başlandı. Anaerop etkinliği olan geniş spektrumlu antibiyotiklere devam edildi. Elektrokardiyografik bulgular bir hafta içinde düzeldi (Resim 2). Genel durumu düzelen, hemodinamik olarak stabil olan hasta ventilatörden ayrıldı ve ekstübe edildi.

\section{Tartışma}

Miyoperikardit, perikardın ve altındaki miyokardiyal dokunun hücresel hasarı ve inflamasyonudur. Semptom ve bulguları belirsiz ve hastalığa özgü olmadığı için, genellikle klinik olarak miyoperikardit tanısı koymak güçtür (2). Ayrıca miyoperikarditin, zaman zaman akut koroner sendromu taklit etmesi de tanısını zorlaştırmaktadır (3). Kesin tanısı ancak histopatolojik olarak konulabilir. Klinikte hafif semptomları olup, tamamen iyileşme ile sonuçlanan hafif veya pek çok vakada olduğu gibi kalp yetersizliği ile seyreden şiddetli miyoperikardit olguları olarak karşımıza çıkabilir (2).

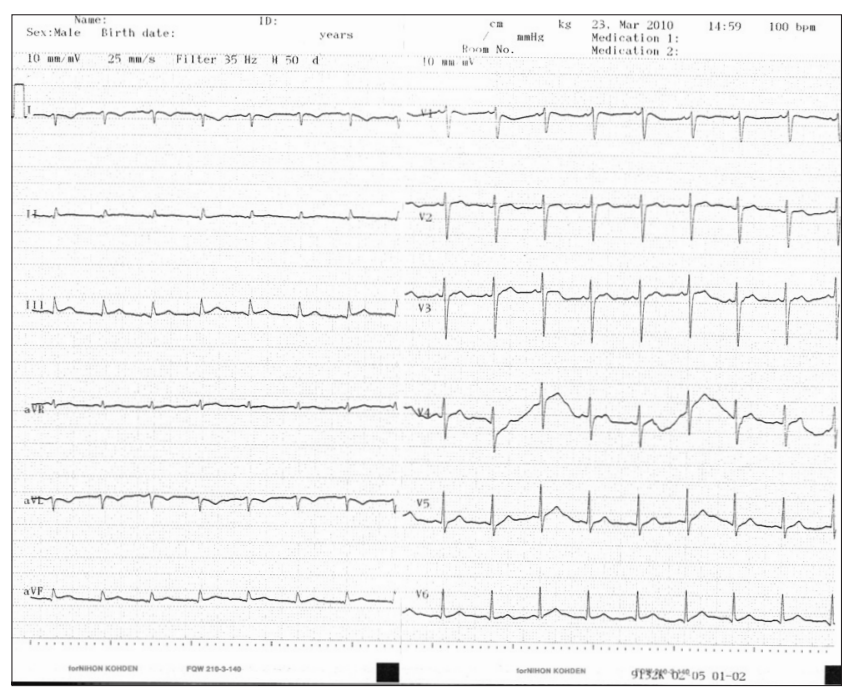

Resim 2. Bir hafta sonraki elektrokardiyogram 
Diş apsesine bağlı derin servikal enfeksiyon ve buna bağlı mediastinit tanısı ile opere olduktan sonra YBÜ'nde entübe ve sedatize olarak izlediğimiz olgumuzda da semptomları değerlendirmek ve tanı için ileri tetkik yapmak zor olduğundan, miyoperikardit tanısı klinik olarak dikkatli değerlendirme sonucunda konmuștur.

Miyoperikarditin sıklıkla viral enfeksiyonlarla ilişkili olarak ortaya çıktığı bildirilmiştir (4-6). Bakteriyel enfeksiyonlarla da miyoperikardit oluşabilir $(7,8)$. Perikarditin elektrokardiyografik bulguları geleneksel olarak tüm derivasyonlarda resiprokal değişiklikler olmaksızın ST yükselmesidir (4). Ancak bazen aVR'de ve bazen de V1'de resiprok ST segment depresyonu olabilir. V1 derivasyonu hariç tüm derivasyonlarda PR segment depresyonu genellikle perikarditi akla getirir. Ama bazen aVR'de PR segmenti yükselebilir. Perikardda sıvı biriktiğinde ise düşük voltajlı QRS görülür (9). Olgumuzda perikardite neden olabilecek bakteriyel mediastinitin olması, koroner arter hastalığı için risk faktörlerinin bulunmaması, kardiyak enzimlerinin hafif yükselmesiyle birlikte ekokardiyografide miyokardiyal fonksiyonlarının normal olması gibi bulgular miyoperikardit tanısını desteklemektedir. Bununla birlikte, bizim olgumuzda inferior derivasyonlarda ve V3, V4 derivasyonlarında ST segment elevasyonu olması nedeniyle, akut koroner sendrom tanısını dışlamak için koroner anjiyografi yapıldı. Literatürde perikardit sırasında fokal EKG değişiklikleri olan ve akut miyokard infarktüsünden ayırt edilemeyen olgu sunumları bildirilmiştir (2,10-12). Tedavileri çok farklı olduğu için, miyoperikardit ve akut miyokard infarktüsünün ayırt edilmesi oldukça önemlidir. Trombolizis ve antikoagülasyon, akut miyokard infarktüsünde temel tedavi yöntemleridir. Ancak miyoperikarditli olgulara trombolitik tedavi uygulanması kardiyovasküler komplikasyonlara neden olabilir. Literatürde perikardit olan ancak perikardit tanısı atlanmış, akut miyokard infarktüsü sanılarak trombolitik ve antikoagülan uygulanmış ve bu tedavi sonrasında kardiyak tamponad gelişmiş olgu sunumları bildirilmiştir $(11,12)$.
Sonuç olarak, akut miyoperikardit ile oluşan EKG bulguları akut miyokardiyal infarktüse benzeyebilir. ST segment yükselmesi olan hastaların ayırıcı tanısında miyoperikardit de düşünülmez ve akut miyokard infarktüsü tedavisi uygulanırsa komplikasyon olasılığı artar. Bu nedenle yoğun bakım hastalarında izlemde ortaya yeni çıkan bulguları değerlendirirken; hastanın öyküsü, klinik durumunun dikkatli değerlendirilmesi, hastaların tedavi planının daha uygun olmasını sağlayacak ve komplikasyonları azaltacaktır.

\section{Kaynaklar}

1. Tarditi DJ, Hollenberg SM. Cardiac arrhythmias in the intensive care unit. Semin Respir Crit Care Med 2006;27:221-9.

2. Omar HR, Fathy A, Rashad R, Elghonemy M. Acute perimyocarditis mimicking transmural myocardial infarction. Int Arch Med 2009;2:37.

3. Pyxaras SA, Lardieri G, Milo M, Vitrella G, Sinagra G. Chest pain and ST elevation: not always ST-segment-elevation myocardial infarction. J Cardiovasc Med (Hagerstown) 2010;11:615-8.

4. Magnani JW, Dec GW. Myocarditis: current trends in diagnosis and treatment. Circulation 2006;113:876-90.

5. Roubille F, Gahide G, Moore-Morris T, Granier M, Davy JM, Vernhet $\mathrm{H}$, et al. Epstein Barr virus (EBV) and acute myopericarditis in an immunocompetent patient: first demonstrated case and discussion. Intern Med 2008:47:627-9.

6. Harada T, Ohtaki E, Tobaru T, Kitahara K, Sumiyoshi T, Hosoda S. Rubella-associated perimyocarditis--a case report. Angiology 2002;53:727-32.

7. Hibbert B, Costiniuk C, Hibbert R, Joseph P, Alanazi H, Simard $\mathrm{T}$, et al. Cardiovascular complications of Salmonella enteritidis infection. Can J Cardiol 2010;26:323-5.

8. Talmon Y, Gilbey P, Fridman N, Wishniak A, Roguin N. Acute myopericarditis complicating acute tonsillitis: beware the young male patient with tonsillitis complaining of chest pain. Ann Otol Rhinol Laryngol 2008;117:295-7.

9. Khan MG. Hızlı EKG yorumu (B. Ilerigelen, B.K. Avcı, Çev.) Istanbul: Istanbul Medikal Yayıncılık; 2007.

10. Shah A. Myocarditis masquerading as a ST elevation myocardial infarction (STEMI). South Med J 2010;103:936-9.

11. Heymann TD, Culling W. Cardiac tamponade after thrombolysis. Postgrad Med J 1994;70:455-6.

12. Blankenship JC, Almquist AK. Cardiovascular complications of thrombolytic therapy in patients with a mistaken diagnosis of acute myocardial infarction. J Am Coll Cardiol 1989;14:1579-82. 